\title{
The economics of phosphorus supplementation of beef cattle grazing northern Australian rangelands
}

\author{
M. K. Bowen A,E , F. Chudleigh ${ }^{\mathrm{B}}$, R. M. Dixon ${ }^{\mathrm{C}}$, M. T. Sullivan ${ }^{\mathrm{A}}$, T. Schatz $^{\mathrm{D}}$ and T. Oxley $^{\mathrm{D}}$ \\ A Department of Agriculture and Fisheries, Rockhampton, PO Box 6014, Red Hill, Qld 4701, Australia. \\ ${ }^{B}$ Department of Agriculture and Fisheries, PO Box 102, Toowoomba, Qld 4350, Australia. \\ ${ }^{\mathrm{C}}$ Queensland Alliance for Agriculture and Food Innovation, CAS, The University of Queensland, Rockhampton, \\ PO Box 6014, Red Hill, Qld 4701, Australia. \\ Department of Primary Industry and Resources, GPO Box 3000, Darwin, NT 0801, Australia. \\ ${ }^{\mathrm{E}}$ Corresponding author. Email: maree.bowen@daf.qld.gov.au
}

\begin{abstract}
Context. Phosphorus $(\mathrm{P})$ deficiency occurs in beef cattle grazing many rangeland regions with low-P soils, including in northern Australia, and may severely reduce cattle productivity in terms of growth, reproductive efficiency and mortality. However, adoption of effective P supplementation by cattle producers in northern Australia is low. This is likely to be due to lack of information and understanding of the profitability of P supplementation where cattle are P-deficient.

Aims. The profitability of P supplementation was evaluated for two dissimilar regions of northern Australia, namely (1) the Katherine region of the Northern Territory, and (2) the Fitzroy Natural Resource Management (NRM) region of central Queensland.

Methods. Property-level, regionally relevant herd models were used to determine whole-of-business productivity and profitability over 30 years. The estimated costs and benefits of $\mathrm{P}$ supplementation were obtained from collation of experimental data and expert opinion of persons with extensive experience of the industry. The economic consequences of $\mathrm{P}$ supplementation at the property level were assessed by comparison of base production without $\mathrm{P}$ supplementation with the expected production of P-supplemented herds, and included the implementation phase and changes over time in herd structure. In the Katherine region, it was assumed that the entire cattle herd (breeders and growing cattle) grazed acutely Pdeficient land types and the consequences of (1) no P supplementation, or P supplementation during (2) the dry season, or (3) both the wet and dry seasons (i.e. 3 scenarios) were evaluated. In the Fitzroy NRM region, it was assumed that only the breeders grazed P-deficient land types with three categories of P deficiency (marginal, deficient and acutely deficient), each with either (1) no P supplementation, or P supplementation during (2) the wet season, (3) the dry season, or (4) both the wet and dry seasons (i.e. 12 scenarios).

Key results. In the Katherine region, year-round $\mathrm{P}$ supplementation of the entire cattle herd (7400 adult equivalents) grazing acutely P-deficient pasture resulted in a large increase in annual business profit (+AU\$500 000). Supplementing with $\mathrm{P}$ (and N) only in the dry season increased annual business profit by $+A U \$ 200000$. In the Fitzroy NRM region, $\mathrm{P}$ supplementation during any season of the breeder herd grazing deficient or acutely P-deficient pastures increased profit by +AU\$2400-AU\$45 000/annum (total cattle herd 1500 adult equivalents). Importantly, P supplementation during the wet season-only resulted in the greatest increases in profit within each category of P deficiency, comprising + AU $\$ 5600$, AU\$6300 and AU\$45000 additional profit per annum for marginal, deficient and acutely P-deficient herds respectively.

Conclusions. The large economic benefits of $\mathrm{P}$ supplementation for northern beef enterprises estimated in the present study substantiate the current industry recommendation that effective P supplementation is highly profitable when cattle are grazing P-deficient land types.

Implications. The contradiction of large economic benefits of $\mathrm{P}$ supplementation and the generally low adoption rates by the cattle industry in northern Australia suggests a need for targeted research and extension to identify the specific constraints to adoption, including potential high initial capital costs.
\end{abstract}

Additional keywords: farm-management economics, P nutrition, P supplementation, tropical pastures.

Received 12 February 2019, accepted 20 July 2019, published online 23 September 2019 


\section{Introduction}

Phosphorus (P) deficiency occurs in cattle grazing many rangeland regions, including in northern Australia, because of low concentrations of $\mathrm{P}$ in soil, and thus pasture, and may severely reduce cattle growth and breeder productivity (Winks 1990; McCosker and Winks 1994). Phosphorus deficiency results in decreased pasture and energy intakes, poor growth, reduced fertility and milk production, and high breeder mortality. In addition, in the absence of vaccination, there is an increased risk of mortality from botulism associated with osteophagia (Dixon et al. 2018).

Phosphorus deficiency of grazing cattle is usually addressed by supplementation to provide additional dietary P. Numerous experiments have reported large increases in voluntary intake of forage (10-40\%), growth rate (up to $100 \mathrm{~kg}$ liveweight/annum) and reproductive performance as weaning rates (10-30\%) and weaner liveweights (10-40 kg liveweight) when P-deficient cattle are fed additional P (Wadsworth et al. 1990; Winks 1990; McCosker and Winks 1994; Jackson et al. 2012). Large effects have also been observed on mortality and morbidity rates (Schatz and McCosker 2018). The biological response to $\mathrm{P}$ supplementation has often been related to the extent of a $\mathrm{P}$ deficiency and rangeland soil $\mathrm{P}$ has been classed as ranging from 'adequate' to 'acutely deficient' (McCosker and Winks 1994).

In growing cattle, $\mathrm{P}$ supplementation is most effective during the wet season when the pasture diet has adequate protein and energy (Winks 1990; Winter et al. 1990; McCosker and Winks 1994). In young growing cattle, this has been clearly demonstrated (Coates et al. 2018). While this also generally occurs for reproducing breeders, the capacity of breeders to mobilise $\mathrm{P}$ in body reserves, especially bone, during pregnancy and lactation during dietary P deficiency, and then replenish this P later in the annual cycle, reduces the seasonality of this effect (Anderson et al. 2017; Dixon et al. 2017). This physiological mechanism allows the reproducing breeder to benefit from $\mathrm{P}$ supplements fed during the dry season and provides a practical strategy to address $\mathrm{P}$ deficiency, even where it is difficult or not possible to feed $\mathrm{P}$ supplements during the wet season in northern beef-cattle production systems.

Despite the extent of $\mathrm{P}$ deficiency across northern Australian rangelands and the large responses to $\mathrm{P}$ supplementation, only a small proportion of cattle grazing these P-deficient rangelands is effectively supplemented with $\mathrm{P}$ during the wet season (Neithe 2011). Lack of information and understanding of the importance of P-deficiency effects on cattle production, and of the profitability of $\mathrm{P}$ supplementation, are likely to be important reasons for the low rates of adoption of management to address nutritional deficiencies of $\mathrm{P}$ on commercial cattle properties (Dixon et al. 2011).

The profitability of alternative management strategies for livestock production is best assessed using property-level herd models that determine the marginal improvement in productivity and profitability (Malcolm 2000). This should also be the case for evaluation of the profitability of $\mathrm{P}$ supplementation for northern Australian beef cattle herds. Principles of economics state that implementation of $\mathrm{P}$ supplementation will enable a beef producer to improve profit, while the marginal revenue received from the beef produced exceeds the marginal cost of the supplement. Calculation of profitability of cattle enterprises requires the estimation of the reduction in mortality rates, and increases in growth and reproduction, from $\mathrm{P}$ supplementation, for all classes of cattle subjected to various categories of $\mathrm{P}$ deficiency. In the present study, the results from experimentation on $\mathrm{P}$ supplementation most relevant to northern Australia were collated, and expert opinion was also obtained, to estimate expected supplementation costs and cattle responses and thus allow a thorough analysis of the economics of $\mathrm{P}$ supplementation at the property level. In the present study, we have applied farm economic analysis to examine the profitability of $\mathrm{P}$ supplementation strategies for a nominal beef cattle enterprise in each of two regions of northern Australia.

\section{Materials and methods}

\section{Approach to economic evaluation}

Two case-study beef cattle enterprises were selected to represent disparate northern Australian cattle-production systems and represented (1) the Katherine region of the Northern Territory (NT) in the seasonally dry tropics and (2) the more endowed subtropical environment of the Fitzroy Natural Resource Management (NRM) region of central Queensland (Q1d). Property-level herd models integrated with economic and financial models were used to determine whole-ofbusiness productivity and profitability over a 30-year investment period. The production of cattle herds and the responses to $\mathrm{P}$ supplementation strategies were estimated from evaluation of the available relevant research and the collation of the expert opinion as described in more detail below. Although supplementation may require additional labour, vehicles, infrastructure and shelter sheds, especially to feed wet-season supplements, such costs were not included in the economic analysis because of their highly variable nature. However, these should be included in more detailed analysis for individual properties. The effects of each $\mathrm{P}$ supplementation strategy were assessed by comparison to a base production system with no $\mathrm{P}$ supplementation. The consequences of change were examined by altering the herd performance and inputs of the base scenario to construct new revised scenarios, and the economic analyses depended on comparison of the base and revised scenarios.

Partial discounted cash flow (DCF) techniques were applied at a 5\% discount rate to calculate the marginal returns associated with additional capital and resources invested within farm operations. Positive marginal returns indicated that marginal costs were likely to be lower than was marginal revenue. The DCF analysis was compiled in real (constant value) terms, with all variables expressed in terms of the price level of the present year (2018). It was assumed that inflation would affect all costs and benefits equally. The Breedcow and Dynama herd budgeting software (Version 6.02; Holmes et al. 2017) applied investment analysis methods as described by Robinson and Barry (1996), Makeham and Malcolm (1993) and Campbell and Brown (2003). The models contained livestock schedules linked to DCF budgets for the base scenarios, and for each alternative scenario. The long 30-year 
analysis interval allowed direct comparison with a larger study where net present values (NPVs) for P supplementation were compared with those for other investments with longer payback periods (Bowen and Chudleigh 2018).

\section{Representative case-study beef cattle enterprises}

\section{(1) Katherine region, NT}

The modelled herd and property was based on data for the ABARES Region 713 (ABS 2012) of the NT and was informed by the 2010 NT Pastoral Industry Survey (Cowley et al. 2015) and relevant regional research (Henderson et al.2012; McGowan et al. 2014). The region has a semiarid monsoonal climate and with distinct wet (rainy; October-April) and dry seasons (May-September). The case-study property was located $600 \mathrm{~km}$ from Darwin and $300 \mathrm{~km}$ from Katherine, and comprised 147000 ha, with a carrying capacity of 7400 adult equivalents (AE). Pastures were primarily native tropical tall grasses growing on acutely P-deficient soil types (2-3 mg/kg bicarbonate-extracted $\mathrm{P}$ (Colwell 1963) in the top $100 \mathrm{~mm}$ of soil; Acute P-deficiency category). The entire cattle herd grazed acutely P-deficient land types. The enterprise was a self-replacing Bos indicus breeding and growing activity, the latter depending on the production of weaners by the breeder herd. Steers and surplus heifers were sold to the live export market (steers $56 \%$ at $1-2$ years, $44 \%$ at 2-3 years; cull heifers at 2-3 years), while cull cows and cull bulls were sold to the abattoirs. The sale prices of livestock were derived from the Darwin live-export markets or from abattoirs in northern Qld (MLA 2018) between July 2006 and November 2016. Livestock sales were calculated net of freight. A detailed description of the herd structures and dynamics, and cattlemanagement activities, treatments and cost assumptions required as inputs for the analysis are given in Chudleigh et al. (2019).

\section{(2) Fitzroy NRM region, central Q/d}

The model property and herd characteristics were informed by recent industry surveys and regional research (McGowan et al. 2014; Bowen et al. 2015; Barbi et al. 2016). The property was located centrally in the Fitzroy NRM region and comprised 8700 ha of native and sown grass pastures with a carrying capacity of $1500 \mathrm{AE}$. The production system was a selfreplacing $B$. indicus crossbred breeding and growing activity that relied on the production of weaners by the breeding herd. The latter utilised the less productive, non-arable land types, which were predominantly open eucalypt woodlands (Whish 2011), with the following three categories of $\mathrm{P}$ deficiency: Marginal, Deficient or Acute defined as 6-8, 4-5 and 2-3 $\mathrm{mg} / \mathrm{kg}$ bicarbonate-extracted P (Colwell 1963) in the top $100 \mathrm{~mm}$ of soil respectively. The steers and heifers grazed more productive and arable Brigalow land types (Whish 2011) supporting sown buffel-grass pastures adequate in P status $(>8 \mathrm{mg} / \mathrm{kg}$ bicarbonateextracted P (Colwell 1963) in the top $100 \mathrm{~mm}$ of soil; Adequate $\mathrm{P}$-deficiency category) and hence required no $\mathrm{P}$ supplementation. In the model, the heifers were mated while grazing buffel-grass pastures and, thereafter, grazed forest country with one of the three designated levels of P status. Feedlot entry-weight steers were sold by auction and cull heifers and cows directly to abattoirs. The price bases for these classes of livestock were derived from Roma store sale data and JBS Australia Dinmore abattoir (Ipswich, Qld) respectively, between July 2008 and November 2015, which were taken to be representative of expected prices expressed in current (real) terms. Livestock sales were calculated net of freight. A detailed description of the herd structures and dynamics, cattle-management activities, treatments and cost assumptions required as inputs for the analysis are given by Bowen and Chudleigh (2018). Freight costs for steers were calculated as described in Bowen et al. (2015).

\section{Alternative production scenarios and P supplementation regimes}

\section{(1) Katherine region, NT}

Three scenarios were modelled including a base of no supplementation or $\mathrm{P}$ supplementation in the form of a mineral loose mix during the dry season only or year-round (Tables 1, 3). Dry-season supplements included N.

\section{(2) Fitzroy NRM region, central Q/d}

Twelve scenarios were modelled encompassing three categories of breeder-herd P status (Marginal, Deficient and Acute, as defined above) each with the base (no supplement) or P supplementation in the form of a mineral loose mix in the wet and/or dry season (Tables 2, 3). Dry-season supplements included $\mathrm{N}$.

\section{Cattle production responses to $P$ supplementation regimes}

For the economic evaluation, it was necessary to estimate the production, and the production responses to $\mathrm{P}$ supplementation, of breeder herds grazing pastures of varying degrees of $\mathrm{P}$ deficiency. Published research of liveweight and reproduction responses to $\mathrm{P}$ supplementation were comprehensively reviewed by Winks (1990) and more recent grazing studies have been reported by Spangenberg (1997), Ternouth and Coates (1997), de Brouwer et al. (2000) and Schatz and McCosker (2018). However, because these studies were usually for one, or at most two, annual cycles, while the adverse effects of $\mathrm{P}$ deficiency may require several years to develop to a new equilibrium (Dixon et al. 2017), it is difficult to use these data to estimate the longer-term consequences of $\mathrm{P}$ supplementation in commercial breeder herds. In addition, information was

Table 1. Supplement loose mix composition (as-fed basis) and cost per tonne for the Katherine region, Northern Territory case-study property with Acute phosphorus (P)-deficiency status

The dry-matter content of minerals was assumed to be $970 \mathrm{~g} / \mathrm{kg}$

\begin{tabular}{lcc}
\hline Parameter & $\begin{array}{c}\text { Wet-season } \\
\text { supplement }\end{array}$ & $\begin{array}{c}\text { Dry-season } \\
\text { supplement }\end{array}$ \\
\hline Urea $(\mathrm{g} / \mathrm{kg})$ & 0 & 300 \\
Ammonium sulfate (GranAm) $(\mathrm{g} / \mathrm{kg})$ & 0 & 100 \\
Calcium phosphate (Kynofos) $(\mathrm{g} / \mathrm{kg})$ & 800 & 200 \\
Salt $(\mathrm{g} / \mathrm{kg})$ & 200 & 400 \\
Crude protein $(\mathrm{g} / \mathrm{kg})$ & 0 & 989 \\
$\mathrm{P}(\mathrm{g} / \mathrm{kg})$ & 168 & 42.0 \\
Supplement cost including freight $(\mathrm{AU} \$ / \mathrm{t})$ & 1340 & 910 \\
\hline
\end{tabular}


Table 2. Supplement loose mix composition (as-fed basis) and cost per tonne for a Fitzroy Natural Resource Management region, central-Queensland case-study property with different levels of phosphorus $(P)$ status

The dry-matter contents of minerals and copra meal were assumed to be 970 and $900 \mathrm{~g} / \mathrm{kg}$ respectively. Marginal-P, marginal P-deficiency status; Deficient-P, deficient P-deficiency status; Acute-P, acute P-deficiency status

\begin{tabular}{|c|c|c|c|c|}
\hline \multirow[t]{2}{*}{ Parameter } & \multirow{2}{*}{$\begin{array}{c}\text { Wet-season supplement } \\
\text { Marginal-, Deficient- and Acute-P herds }\end{array}$} & \multicolumn{3}{|c|}{ Dry-season supplement } \\
\hline & & Marginal-P herd & Deficient-P herd & Acute-P herd \\
\hline Urea $(g / k g)$ & 0 & 300 & 300 & 300 \\
\hline Ammonium sulfate (GranAm), (g/kg) & 0 & 80 & 80 & 80 \\
\hline Copra meal $(\mathrm{g} / \mathrm{kg})$ & 0 & 100 & 100 & 100 \\
\hline Calcium phosphate (Kynofos), (g/kg) & 800 & 60 & 120 & 170 \\
\hline Salt $(\mathrm{g} / \mathrm{kg})$ & 200 & 460 & 400 & 350 \\
\hline Crude protein $(\mathrm{g} / \mathrm{kg})$ & 0 & 985 & 985 & 985 \\
\hline $\mathrm{P}(\mathrm{g} / \mathrm{kg})$ & 168 & 13.1 & 25.7 & 36.2 \\
\hline Supplement cost including freight (AU\$/t) & 1309 & 835 & 888 & 932 \\
\hline
\end{tabular}

Table 3. Supplement and nutrient intakes for cattle in the Katherine and the Fitzroy Natural Resource Management (NRM) regions supplemented with mineral loose mix supplements in the wet and/or dry season, containing nitrogen $(\mathrm{N})$ and/or phosphorus (P), for scenarios covering land types and cattle herds marginally (Marginal-P), deficient (Deficient-P) and acutely (Acute-P) deficient in $P$

Scenario

Days fed supplement

$\begin{array}{ll}\text { Supplement } & \text { Crude protein } \\ \text { (g/head.day) } & \text { (g/head.day) }\end{array}$

$\mathrm{P}$ (g/head.day)

Wet season Dry season Wet season Dry season Wet season Dry season Wet season Dry season

Katherine region property, Northern Territory (supplementation of all cattle)

(1) Acute-P herd, no supplement (base scenario)

0

0

0

$0 \quad 0$

0

0

(2) Acute-P herd, dry-season N+P

Breeders

Yearling cattle

Weaners

$0 \quad 200$

$0 \quad 200$

$0 \quad 120$

$0 \quad 155$

$0 \quad 100$

(3) Acute-P herd, dry-season $\mathrm{N}+\mathrm{P}$, wet-season $\mathrm{P}$

Breeders

$150 \quad 200$

Yearling cattle

150

200

0

100
80

0

0

153

99

79

Weaners

$\mathrm{n} / \mathrm{a} \quad 120$

$\begin{array}{cc}80 & 160 \\ 40 & 105 \\ \text { n/a } & 80\end{array}$

160
105

80

0

158

104

13.4

6.7

$\mathrm{n} / \mathrm{a}$

Fitzroy NRM region property, central Queensland (supplementation of breeders only)

(1) Marginal-P herd, no supplement (base scenario)

(2) Marginal-P herd, wet-season $\mathrm{P}$

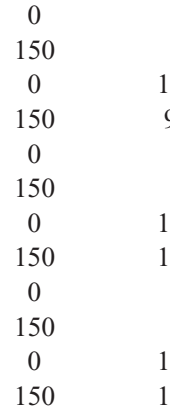

$\begin{array}{ccc}0 & 0 & 0 \\ 0 & 20 & 0 \\ 120 & 0 & 155 \\ 90 & 20 & 155 \\ 0 & 0 & 0 \\ 0 & 60 & 0 \\ 150 & 0 & 155 \\ 120 & 60 & 155 \\ 0 & 0 & 0 \\ 0 & 81 & 0 \\ 180 & 0 & 155 \\ 150 & 81 & 155\end{array}$

0
0
0
0
0
0
0
0
0
0
0
0

$\begin{array}{ccc}0 & 0 & 0 \\ 0 & 3.4 & 0 \\ 153 & 0 & 2.0 \\ 153 & 3.4 & 2.0 \\ 0 & 0 & 0 \\ 0 & 10.1 & 0 \\ 153 & 0 & 4.0 \\ 153 & 10.1 & 4.0 \\ 0 & 0 & 0 \\ 0 & 13.6 & 0 \\ 153 & 0 & 5.6 \\ 153 & 13.6 & 5.6\end{array}$

generally lacking to allocate the reported studies to categories of rangeland-soil $\mathrm{P}$ deficiency for grazing cattle. Thus, the published literature was considered inadequate to estimate the responses to $\mathrm{P}$ supplementation of various classes of cattle grazing pastures ranging in $\mathrm{P}$ deficiency. Therefore, the cattle production responses to various strategies of supplementation with $\mathrm{P}$ and $\mathrm{N}$, for the two representative properties, were estimated by evaluating published and unpublished research and also collating the expert opinion of scientists and beef extension officers with extensive knowledge of the northern Australian cattle industry. It must be emphasised that the 'typical' responses estimated by this expert opinion were usually much lower (often less than half) than were the responses reported in some formal research experiments. This approach was adopted for two reasons. First, the responses to additional inputs on commercial farms and cattle properties are generally expected to be much lower than the responses in formal research usually conducted under closely controlled conditions and with rigorous application of designated treatments (Davidson and Martin 1965; Dillon and Anderson 1990). Second, it was considered desirable to adopt conservative estimates of cattle production responses to reduce the risk of obtaining overly optimistic conclusions on the benefits of $\mathrm{P}$ supplementation. 
The estimated impacts on breeder liveweight, mortality and weaning rates and weaner liveweight of supplementation during the wet season, the dry season, or both the wet and dry seasons for various categories of P-deficiency status in the Fitzroy NRM region in central Q1d, and for the Acute P-deficiency category in the Katherine region of the NT, northern Australia, are given in Table 4. Mortality rates were assigned with the assumption that all cattle were vaccinated for botulism regardless of $\mathrm{P}$ supplementation. An important assumption was that although $\mathrm{P}$ was the primary limiting factor for breeder performance at each level of P-deficiency status, the $\mathrm{P}$ supplementation program would not increase the performance of the Deficient or Acutely P-deficient breeder herds to the same level of performance as that of the Adequate-P breeder herds, due to other nutritional constraints expected to be associated with Deficient or Acutely P-deficient land-type categories (Kerridge et al. 1990; Coates et al. 1997). In the herd models, the numbers of breeders in the supplemented scenario herds were reduced to account for the higher average liveweight of supplemented breeders and to maintain an equivalent grazing pressure. Each supplementation scenario was modelled to include the effects of implementing the change. Herd structures changed as reproductive efficiency and mortality rates changed and cow and heifer numbers were adjusted to maintain the same grazing pressure. Cull cows, cull bulls and heifers were sold at the same age regardless of the supplementation strategy, but at heavier liveweights. The sale age for steers was maintained the same, except for the Katherine herd when fed P supplements all year. In this case, the first and subsequent cohorts of steers were sold 1 year earlier due to their improved liveweight gain. Sale prices (AU\$ $/ \mathrm{kg}$ ) were not changed with supplementation strategy. During the modelling calculations, although breeder cows were fed supplement during Year 1, it was assumed that their reproductive efficiency, liveweight and mortality rates did not begin to change until Year 2 and the new levels of performance were achieved by Year 5. Also, additional weaners produced by implementation of the supplementation program did not add to the returns to the property until they were sold. In the Katherine region, where steers and heifers grazed Acute-P status country after weaning, their assumed annual growth increase due to year-round $\mathrm{P}$ supplementation was $30 \mathrm{~kg} / \mathrm{head}$, as reported by Schatz and McCosker (2018). Steers and heifers receiving only dry-season supplementation were assumed to achieve an annual growth increase of $10 \mathrm{~kg} / \mathrm{head}$ (Dixon and Doyle 1996). In the Fitzroy NRM region, although weaner liveweight was reduced due to the breeder herds grazing P-deficient land systems, it was assumed that both the steers and heifers fully compensated in liveweight post-weaning and before sale or entry to the breeder herd. This was based on these cattle grazing P-adequate brigalow land types (Whish 2011) post-weaning and on the experiments of Tudor and O'Rourke (1980).

\section{Economic and financial criteria used to evaluate $P$ supplementation scenarios}

The economic criteria calculated were the marginal NPV at the required real rate of return $(5 \%$; as the real opportunity cost of funds to the producer) and the internal rate of return (IRR). The marginal NPV was calculated over the 30-year life of the investment, expressed in present-day terms at the level of operating profit. The latter was calculated as:

Operating profit

$=($ total receipts - variable costs $=$ total gross margin $)-$ overheads.

Hence, the operating profit was defined as the return to total capital invested after the variable and overhead (fixed) costs involved in earning the revenue were deducted. Operating profit represented the reward to all of the capital managed by the business and was calculated net of an allowance for the labour and management of the owner. Opening and salvage values for land, plant and livestock were applied at the beginning and end of the DCF analysis, to capture the opening and residual value of assets. Plant replacement was incurred as a capital cost less a salvage value in the year it was expected to be incurred during the investment period. An amortised NPV was calculated at the discount rate over the investment period to assist in communicating the difference between the base property and the property after the management strategy was implemented. This amortised NPV measure is not the same as the annual difference in operating profit between the two strategies, but it is presented to identify the approximate annual average improvement in profit generated by the implementation of the $\mathrm{P}$ supplementation strategy. The IRR was calculated as the discount rate at which the present value of income equalled the present value of total expenditure (capital and annual costs), i.e. the break-even discount rate.

The financial criteria calculated were peak deficit, the number of years to the peak deficit, and the payback period in years. The beef enterprise started with no debt, but debt was accumulated and interest paid as required for the implementation of a $\mathrm{P}$ supplementation strategy. Peak deficit in cash flow was calculated assuming interest was paid on the deficit and compounded for each additional year in the investment period. The payback period was calculated as the number of years taken for the cumulative present value to become positive.

\section{Results}

\section{(1) Katherine region, NT}

Effective P supplementation of Acutely P-deficient breeder herds increased weaners produced per total cows mated and decreased breeder mortality, and this resulted in increased female sales as a proportion of total sales (Table 5). These effects resulted in substantial changes to the structure of the herd over time. After implementing year-round $\mathrm{P}$ supplementation, the case-study property reduced breeder herd size from 5117 to 4382 (i.e. 735 fewer breeders), but increased the number of weaners by 512. In addition, the property sold 780 more cull cows and heifers and 448 more steers and bullocks.

The net profit per annum (undiscounted) of the base property with no $\mathrm{P}$ supplementation was AU\$310000. Phosphorus supplementation year-round resulted in a very large increase (+AU\$500 000) in the annualised NPV with a relatively low financial risk, as measured by the peak deficit (-AU\$360000) and the payback period of 3 years (Table 7). The IRR resulting from year-round $P$ 
Table 4. Estimated response to phosphorus (P) supplementation strategies for cattle herds grazing land types adequate in $P$ (Adequate-P), or marginally (Marginal-P), deficient (Deficient-P) and acutely (Acute-P) deficient in $\mathbf{P}$

LW, liveweight; $\mathrm{N}$, nitrogen

\begin{tabular}{|c|c|}
\hline \multirow[t]{2}{*}{ Parameter } & P status of grazing land and cattle \\
\hline & Adequate-P \\
\hline
\end{tabular}

Katherine region property, Northern Territory

Average cow LW over 12 months $(\mathrm{kg})$

(1) No P or N (base scenario)

(2) Dry-season $\mathrm{N}+\mathrm{P}$

(3) Dry-season N+P, wet-season P

Cull-cow LW in June (kg)

(1) No P or N (base scenario)

(2) Dry-season $\mathrm{N}+\mathrm{P}$

(3) Dry-season N+P, wet-season P

Breeder mortality rate (\%)

(1) No P or N (base scenario)

(2) Dry-season N+P

(3) Dry-season N+P, wet-season P

Weaning rate $(\%)$

(1) No P or N (base scenario)

(2) Dry-season $\mathrm{N}+\mathrm{P}$

(3) Dry-season $\mathrm{N}+\mathrm{P}$, wet-season $\mathrm{P}$

Weaner LW at 6 months $(\mathrm{kg})$

(1) No P or N (base scenario)

(2) Dry-season $\mathrm{N}+\mathrm{P}$

(3) Dry-season N+P, wet-season P

Annual steer LW gain $(\mathrm{kg} / \mathrm{head})$

(1) No P or N (base scenario)

(2) Dry-season $\mathrm{N}+\mathrm{P}$

(3) Dry-season $\mathrm{N}+\mathrm{P}$, wet-season $\mathrm{P}$

Fitzroy Natural Resource Management region property, central Queensland

Average cow LW over 12 months $(\mathrm{kg})$

(1) No P or N (base scenario)

(2) Wet-season $P$

(3) Dry-season N+P

(4) Dry-season N+P, wet-season P

Cull-cow LW in June (kg)

(1) No P or N (base scenario)

(2) Wet-season $P$

(3) Dry-season N+P

(4) Dry-season $\mathrm{N}+\mathrm{P}$, wet-season $\mathrm{P}$

Breeder mortality rate (\%)

(1) No P or N (base scenario)

(2) Wet-season P

(3) Dry-season N+P

(4) Dry-season N+P, wet-season P

Weaning rate $(\%)$

(1) No P or N (base scenario)

(2) Wet-season P

(3) Dry-season $\mathrm{N}+\mathrm{P}$

(4) Dry-season N+P, wet-season P

Weaner LW at 6 months $(\mathrm{kg})$

(1) No P or N (base scenario)

(2) Wet-season $P$

(3) Dry-season N+P

(4) Dry-season N+P, wet-season P

$\begin{array}{llll} & & & 400 \\ - & - & - & 420 \\ - & - & - & 450 \\ & & & 390 \\ - & - & - & 410 \\ - & - & - & 440 \\ & & & 10 \\ - & - & - & 6 \\ - & - & - & 3 \\ & & & 45 \\ - & - & - & 55 \\ - & - & - & 65 \\ & & & 160 \\ - & - & - & 170 \\ - & - & - & 190 \\ - & - & - & 80 \\ - & - & - & 90 \\ - & - & - & 110\end{array}$

$\begin{array}{ll}460 & 450 \\ 460 & 460 \\ 460 & 460 \\ 460 & 460 \\ & \\ 440 & 430 \\ 440 & 440 \\ 440 & 440 \\ 440 & 440\end{array}$

$\begin{array}{lll}450 & 435 & 428 \\ 460 & 450 & 445 \\ 460 & 445 & 435 \\ 460 & 455 & 450 \\ & & \\ 430 & 410 & 400 \\ 440 & 425 & 418 \\ 440 & 420 & 412 \\ 440 & 430 & 425\end{array}$

$\begin{array}{llll}2 & 4 & 6 & 9 \\ 2 & 2 & 4 & 5 \\ 2 & 2 & 4 & 5 \\ 2 & 2 & 3 & 3 \\ 77 & & 67 & 57 \\ 77 & 72 & 73 & 72 \\ 77 & 77 & 72 & 67 \\ 77 & 77 & 75 & 73 \\ & 77 & & \\ 200 & & 175 & 168 \\ 200 & 190 & 190 & 180 \\ 200 & 200 & 190 & 180 \\ 200 & 200 & 195 & 190\end{array}$

supplementation was $172 \%$. The average annual cash surplus over the 30 years increased from AU\$318 000 to AU\$871 000 (i.e. 1.7 times). The impacts of the changes in growth, fertility and mortality in the P-supplemented herd, examined by their individual removal after the model had stabilised, indicated that the increased growth rates contributed $12 \%$ of the herd gross margin, the increased fertility $41 \%$, and decreased mortality rates $33 \%$. 


\section{(2) Fitzroy NRM region, central Q/d}

Effective P supplementation of P-deficient breeder herds in this region also increased weaners produced per cows mated and decreased breeder mortality, and, consequently, increased female sales as a proportion of total sales (Table 6). These resulted in substantial changes to the structure of the herd over time, particularly for Acutely P-deficient herds.

The net profit per annum (undiscounted) of the base property with no P supplementation was AU\$110 000, AU\$88 000 and AU\$33000 for Marginal-, Deficient- and Acute-P status properties respectively. The returns from $\mathrm{P}$ supplementation increased with increasingly severe P-deficiency status of the breeder herd; annualised NPVs for wet-season only $\mathrm{P}$ supplementation of the breeder herd were +AU\$5600,

Table 5. Modelled production outputs for the Katherine region, Northern Territory case-study enterprise on Acutely P-deficient land types with no supplementation or with phosphorus $(P)$ supplementation in the dry season or year-round

\begin{tabular}{lccc}
\hline Parameter & $\begin{array}{c}\text { No P } \\
\text { or N }\end{array}$ & $\begin{array}{c}\text { Dry-season } \\
\text { N+P }\end{array}$ & $\begin{array}{c}\text { Dry-season N+P, } \\
\text { wet-season P }\end{array}$ \\
\hline Total adult equivalents & 7400 & 7400 & 7400 \\
Total cattle carried & 9936 & 9463 & 8722 \\
Weaner heifers retained & 1160 & 1280 & 1416 \\
Total breeders mated & 5117 & 4693 & 4382 \\
Total breeders mated and retained & 4911 & 4095 & 3450 \\
Total calves weaned & 2319 & 2559 & 2831 \\
Weaners/total cows mated (\%) & 45.3 & 54.5 & 64.6 \\
Overall breeder deaths (\%) & 10 & 6 & 3 \\
Maximum cow-culling age (years) & 12 & 12 & 12 \\
Total cows and heifers sold & 448 & 885 & 1228 \\
Total steers and bullocks sold & 898 & 1118 & 1346 \\
Female sales/total sales (\%) & 33.3 & 44.2 & 47.7 \\
\hline
\end{tabular}

+AU\$6300 and +AU\$45000 for Marginal, Deficient and Acutely P-deficient herds respectively (Table 7). Phosphorus supplementation of the breeders only in the wet season provided larger returns than did supplementing with $\mathrm{N}+\mathrm{P}$ during the dry season, or supplementing with $\mathrm{N}+\mathrm{P}$ during the dry season in combination with P supplementation during the wet season. In the Marginal-P status land type, supplementing the breeder herd during the dry season-only or year-round resulted in a small decrease in the calculated NPV. For breeder herds grazing pastures Deficient or Acutely deficient in P, supplementation in any season increased profitability (range +AU $\$ 2400-A U \$ 45000$ additional profit/annum). For the Acute-P status land type with $\mathrm{P}$ supplementation in the wet season only, the IRR for the investment in supplementation was $81 \%$ and the average annual cash surplus increased from AU $\$ 40000$ to AU $\$ 90000$ due to supplementation (i.e. 1.3 times).

\section{Discussion}

\section{The important factors causing increased economic returns to $P$ supplementation}

The economic analyses indicated that effective $P$ supplementation of cattle grazing P-deficient or acutely P-deficient land systems substantially increased the profitability of beef enterprises in northern Australia. The large economic benefits calculated for the Katherine region case-study property were greater than the estimated increase in herd gross margin for acutely P-deficient cattle properties reported by Jackson et al. (2012); this was mostly associated with a substantially greater estimated effect of $\mathrm{P}$ supplementation on breeder mortality rate in the present study. The present study indicated that the large estimated decrease in mortality in acutely P-deficient herds due to P supplementation is a key contributing factor to the improved profitability. For the Katherine region case-study, this contributed $\sim 33 \%$ of the total benefit of $\mathrm{P}$ supplementation on the herd gross margin. In

Table 6. Modelled production outputs for the Fitzroy Natural Resource Management region, central Queensland case-study enterprise with phosphorus (P) supplementation strategies for breeding herds grazing land types either marginally (Marginal-P), deficient (Deficient-P) or acutely (Acute-P) deficient in $\mathbf{P}$

\begin{tabular}{|c|c|c|c|c|c|c|c|c|c|c|}
\hline \multirow[t]{2}{*}{ Parameter } & \multicolumn{10}{|c|}{ P status of grazing land and cattle } \\
\hline & \multicolumn{2}{|c|}{ Marginal-P } & \multicolumn{4}{|c|}{ Deficient-P } & \multicolumn{4}{|c|}{ Acute-P } \\
\hline Total adult equivalents & 1500 & 1500 & 1500 & 1500 & 1500 & 1500 & 1500 & 1500 & 1500 & 1500 \\
\hline Total cattle carried & 1643 & 1627 & 1671 & 1645 & 1650 & 1638 & 1696 & 1646 & 1654 & 1643 \\
\hline $\begin{array}{l}\text { Total breeders mated } \\
\text { and retained }\end{array}$ & 572 & 565 & 593 & 572 & 574 & 569 & 729 & 573 & 612 & 571 \\
\hline Total calves weaned & 531 & 527 & 533 & 532 & 533 & 530 & 476 & 532 & 515 & 531 \\
\hline Weaners/total cows mated $(\%)$ & 72 & 77 & 67 & 73 & 72 & 75 & 57 & 72 & 67 & 73 \\
\hline Overall breeder deaths (\%) & 4 & 2 & 6 & 4 & 4 & 3 & 9 & 5 & 5 & 3 \\
\hline $\begin{array}{l}\text { Maximum cow-culling } \\
\text { age (years) }\end{array}$ & 13 & 13 & 13 & 13 & 13 & 13 & 13 & 13 & 13 & 13 \\
\hline
\end{tabular}

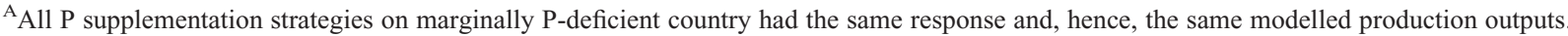


Table 7. Profitability and financial risk of implementing phosphorus (P) supplementation strategies for (1) an Acutely P-deficient cattle herd in the Katherine region (Acute-P) supplemented in the dry season or year-round and (2) breeder herds in the Fitzroy Natural Resource Management (NRM) region that were either marginally (Marginal-P), deficient (Deficient-P) or acutely (Acute-P) deficient in P and were supplemented in the wet and/or the dry seasons

NPV is the net present value of an investment, referring to the net returns (income minus costs) over the 30 -year life of the investment and represents the extra return added by the management strategy, i.e. it is the difference between the base, case-study property with no P supplementation and the same property after the $\mathrm{P}$ supplementation strategy is implemented. The annualised NPV represents the average annual change in NPV over 30 years, resulting from the P supplementation strategy, and can be considered as an approximation of the change in profit per year. Peak deficit is the maximum difference in cash flow between the $P$ supplementation strategy and the base scenario over the 30 -year period of the analysis. It is a measure of riskiness. Payback period is the number of years it takes for the cumulative present value to become positive. Other things being equal, the shorter the payback period, the more appealing the investment. IRR is the internal rate of return, i.e. the rate of return on the additional capital invested. It is a discounted measure of project worth. n/c, not calculable

\begin{tabular}{|c|c|c|c|c|c|c|}
\hline Strategy & $\begin{array}{l}\text { NPV of } \\
\text { change }\end{array}$ & $\begin{array}{l}\text { Annualised } \\
\text { NPV }\end{array}$ & $\begin{array}{c}\text { Peak deficit } \\
\text { (with interest) }\end{array}$ & $\begin{array}{c}\text { Years to } \\
\text { peak deficit }\end{array}$ & $\begin{array}{c}\text { Payback period } \\
\text { (years) }\end{array}$ & $\operatorname{IRR}(\%)$ \\
\hline \multicolumn{7}{|c|}{ Katherine region, Northern Territory } \\
\hline Acute-P herd, dry-season $\mathrm{N}+\mathrm{P}$ & AU\$3 015469 & AU\$196161 & $-\mathrm{AU} \$ 363738$ & 3 & 3 & 60 \\
\hline Acute-P herd, dry-season $\mathrm{N}+\mathrm{P}$, wet-season $\mathrm{P}$ & AU\$7 691352 & AU $\$ 500334$ & $-A U \$ 359780$ & 3 & 3 & 172 \\
\hline \multicolumn{7}{|c|}{ Fitzroy NRM region, central Queensland } \\
\hline Marginal-P breeders, wet-season P & AU\$86 137 & AU $\$ 5603$ & -AU\$7187 & 3 & 3 & 114 \\
\hline Marginal-P breeders, dry-season $\mathrm{N}+\mathrm{P}$ & $-\mathrm{AU} \$ 3576$ & $-A U \$ 233$ & -AU\$34 107 & $\mathrm{n} / \mathrm{c}$ & $\mathrm{n} / \mathrm{c}$ & 3 \\
\hline Marginal-P breeders, dry-season $\mathrm{N}+\mathrm{P}$, wet-season $\mathrm{P}$ & -AU\$18 434 & -AU\$1199 & -AU\$61 210 & $\mathrm{n} / \mathrm{c}$ & $\mathrm{n} / \mathrm{c}$ & -4 \\
\hline Deficient-P breeders, wet-season $\mathrm{P}$ & AU\$96 874 & AU\$6302 & -AU\$26907 & 3 & 3 & 52 \\
\hline Deficient-P breeders, dry-season $\mathrm{N}+\mathrm{P}$ & AU\$56 247 & AU\$3659 & -AU\$37094 & 3 & 4 & 25 \\
\hline Deficient-P breeders, dry-season $\mathrm{N}+\mathrm{P}$, wet-season $\mathrm{P}$ & AU\$36 655 & AU\$2384 & -AU\$57965 & 3 & 14 & 14 \\
\hline Acute-P breeders, wet-season $\mathrm{P}$ & AU\$695035 & AU\$45 213 & -AU\$38 877 & 3 & 3 & 81 \\
\hline Acute-P breeders, dry-season $\mathrm{N}+\mathrm{P}$ & AU\$435778 & AU\$28 348 & -AU\$56453 & 3 & 4 & 49 \\
\hline Acute-P breeders, dry-season $\mathrm{N}+\mathrm{P}$, wet-season $\mathrm{P}$ & AU\$630 094 & AU\$40 989 & -AU\$87 535 & 3 & 4 & 47 \\
\hline
\end{tabular}

situations where the mortality rate of unsupplemented breeders is as high as the $27 \%$ implied by Schatz and McCosker (2018), the impact of reduced mortality due to $\mathrm{P}$ supplementation on the economic performance of the herd would be substantially greater than that estimated in the present study. An important related issue is that the regions in northern Australia with the highest rates of breeder mortality are generally also regions with the acutely P-deficient soils and low levels of infrastructure, herd control and adoption of $\mathrm{P}$ supplementation (Henderson et al. 2012). Phosphorus supplementation is only one aspect of "whole of property management' (Foran et al. 1990; Henderson et al. 2012) and substantial changes to herd and property management may be required as part of the changes necessary to implement $\mathrm{P}$ supplementation. A further consideration is that it would be desirable to examine the economic returns from $\mathrm{P}$ supplementation on an individual-property basis to account for specific aspects such as location, capability of the land systems, herd size and performance, input and output costs and the attitude of the current management to risk.

In the more benign environment of the Fitzroy NRM region case study, because the assumption included that the steers were weaned on to buffel-grass pastures and sold at the same liveweight regardless of the $\mathrm{P}$ status of the breeder herd, all of the economic and financial benefits were associated with the reduced breeder mortality rates, increased weaning percentages and increased sale liveweights of cull cows. In the Katherine case-study property, a decrease in cow-culling age could be made possible by the increased herd productivity, further contributing to improved economic performance and providing additional benefits in reducing drought risk. However, this aspect was not considered in the present study. In the Fitzroy NRM region casestudy property, optimal cow-cull age was not affected by $\mathrm{P}$ supplementation in the analysis used; this was in accord with the conclusion of McGowan et al. (2014) that there was no critical decrease in breeder performance with age in the relatively benign environment of this region. A further important observation from the Fitzroy NRM region case study was that $\mathrm{P}$ supplementation only during the wet season was the most profitable. Supplementation with $\mathrm{N}+\mathrm{P}$ only during the dry season, or supplementation with $\mathrm{N}+\mathrm{P}$ during the dry season combined with supplementation with $\mathrm{P}$ during the wet season, increased the costs of supplementation compared with the wetseason $\mathrm{P}$ strategy, with minimal differences in herd performance.

A cost in implementing a $P$ supplementation program that was not included in the present evaluations is the direct on-farm cost associated with delivering $\mathrm{P}$ supplements other than the purchase and delivery to the property. This includes the potential capital costs, for feed-supplement sheds for wet-season feeding and additional trucks and machinery, and also the labour and vehicle costs of feeding supplements. These costs can be substantial, but we elected not to include them in the analysis because they will be highly variable among properties. At one extreme where supplement-feeding sheds are already in place (e.g. for feeding dry-season urea supplements) and reticulated water points have to be checked frequently as part of routine management, then arguably the additional capital, labour and vehicle costs will be minor. At the other extreme, where supplement sheds need to be purchased as constructed units (e.g. one shed at AU\$1000 per 150 head), where use of reliable surface water points require little oversight, and 
specialist vehicles, machinery and labour may be required for supplement feeding, the cost may be substantial. For example, for a 7500-AE property that might require an investment in feeding troughs or sheds, dedicated truck and other machinery the capital cost of implementation might be AU\$5-AU\$15 per AE. We suggest that because such costs will be highly specific to individual businesses, it is appropriate not to include them in the present generic economic analyses, while recommending that they be included in analyses for individual properties. Regardless, these costs, while potentially substantial in Year 1 of implementing a supplementation program and increasing the peak deficit, are minor in relation to the overall economic benefits of $\mathrm{P}$ supplementation.

The present study supports best-practice industry recommendations such as described by Jackson et al. (2012) to undertake the best possible evaluation of the $\mathrm{P}$ status of the herd before undertaking any supplementation program. Where there is little or no production response to $\mathrm{P}$ supplementation, then no economic benefit can be expected. Breeder herds in the Fitzroy NRM region of central Qld performing at the median or high level in regional surveys (McGowan et al.2014) are likely to have adequate $\mathrm{P}$ status and, hence, are unlikely to show an economic response to $\mathrm{P}$ supplementation. However, those that are grazing acutely deficient $P$ status land types are likely to show a strong economic response to appropriate $\mathrm{P}$ supplementation.

\section{Reliability of the economic evaluation}

The economic analyses used in the present study depended on (1) estimation of the production responses, particularly of breeder herds, to $\mathrm{P}$ supplementation under various sets of circumstances, and (2) the cost of the implementation of an effective $\mathrm{P}$ supplementation program. Each of these issues presents challenges. As discussed above, the estimated responses of cattle to $\mathrm{P}$ supplementation were based on the best expertise available and were deliberately conservative in relation to much reported research, but, by necessity, they were subjective and had to encompass a wide range of circumstances of region, cattle management and within- and between-year variation. Hence, the estimates of the expected changes in cattle production adopted here, and the associated economic responses, must be considered only as guidelines. Second, estimating diet $\mathrm{P}$ intake by grazing cattle, and their body $\mathrm{P}$ reserves, is difficult (McCosker and Winks 1994; Dixon et al. 2016, 2017; Anderson et al. 2017). This is especially difficult where paddocks include several major soil types such as areas of alluvial soils expected to be high in $\mathrm{P}$ as well as soils expected to be low in P. Third, it has long been recognised that there are often difficulties when feeding loose mineral mix or feedblock supplements to achieve target intakes of a mineral such as $\mathrm{P}$ by grazing cattle. There is often poor acceptance of such supplements by cattle grazing wet-season pastures, and usually a high variability among animals and the presence of many noneaters of supplement within herds (Dixon 1998; Dixon et al. 2003). An additional consideration is that although the highest economic responses are expected to occur to $\mathrm{P}$ supplementation during the wet season, this is often difficult to achieve in practice. Although the provision of $\mathrm{N}+\mathrm{P}$ supplements during the dry season is less effective and efficient for cattle production and is expected to provide a lower economic benefit, this may be the only option for some commercial cattle property situations. Thus, evaluation of the appropriate P category of pasture systems and the implementation of effective and efficient $\mathrm{P}$ supplementation are associated with considerable uncertainty and there are obstacles to the prediction of cattle production and economic responses. However, this uncertainty should be balanced by the conservative estimates of the cattle-production responses used in this analysis and the positive responses identified by trials conducted at a paddock scale under semi-commercial conditions (Schatz and McCosker 2018).

In conclusion, the large economic benefits of $\mathrm{P}$ supplementation for northern beef enterprises estimated in the present study are in accord with previous studies (Holmes 1990; McCosker and Winks 1994; Jackson et al. 2012) and should support increased adoption of $\mathrm{P}$ supplementation in land systems where $\mathrm{P}$ deficiency occurs. Assessment of the benefits of $\mathrm{P}$ supplementation should ideally be undertaken on an individual-property basis and with consideration of current management to identify the most appropriate changes for each business.

\section{Conflicts of interest}

R. M. Dixon is an associate editor for Animal Production Science but had no involvement in the evaluation of the manuscript.

\section{Acknowledgements}

This study was co-funded by the Department of Agriculture and Fisheries, Queensland, and the Queensland Government Drought and Climate Adaptation Program. The authors have benefitted from numerous discussions and input provided by many producers, scientists and staff of companies providing technical services to the northern beef industry, and especially beef cattle research and extension specialists within Qld and NT Governments.

\section{References}

ABS (2012) '7121.0. Agricultural commodities, Australia, 2010-11.' Available at http://www.abs.gov.au/AUSSTATS/abs@.nsf/Details Page/7121.02010-11 [Verified August 2018]

Anderson ST, Kidd LJ, Benvenutti MA, Fletcher MT, Dixon RM(2017) New candidate markers of phosphorus status in beef breeder cows. Animal Production Science 57, 2291-2303. doi:10.1071/AN17363

Barbi E, Moravek T, Anderson A (2016) The 2011-14 reef catchments beef industry survey report. State of Queensland, Department of Agriculture and Fisheries, Brisbane, Qld, Australia.

Bowen MK, Chudleigh F (2018) 'Fitzroy beef production systems. Preparing for, responding to, and recovering from drought.' (The State of Queensland, Department of Agriculture and Fisheries, Queensland: Brisbane, Qld, Australia) Available at https://futurebeef.com.au/ projects/improving-profitability-and-resilience-of-beef-and-sheepbusinesses-in-queensland-preparing-for-responding-to-and-recoveringfrom-drought/ [Verified June 2019]

Bowen MK, Chudleigh F, Buck S, Hopkins K, Brider J (2015) High-output forage systems for meeting beef markets: Phase 2. Project B.NBP.0636 final report. Meat and Livestock Australia, Sydney, NSW, Australia.

Campbell HF, Brown RP (2003) 'Benefit-cost analysis. Financial and economic appraisal using spreadsheets.' (Cambridge University Press: Cambridge, UK)

Chudleigh F, Oxley T, Bowen M (2019) 'Improving the performance of beef enterprises in northern Australia.' (The State of Queensland, Department of Agriculture and Fisheries: Brisbane, Qld) Available at https://www. 
daf.qld.gov.au/animal-industries/beef/breedcow-and-dynama-software [Verified June 2019]

Coates DB, Miller CP, Hendricksen RE, Jones RJ (1997) Stability and productivity of Stylosanthes pastures in Australia. II. Animal production from Stylosanthes pastures. Tropical Grasslands 31, 494-502.

Coates DB, Dixon RM, Murray RM, Mayer RJ, Miller CP (2018) Bone mineral density in the tail-bones of cattle: effect of phosphorus status, liveweight, age and physiological status. Animal Production Science 58, 801-810. doi:10.1071/AN16376

Colwell JD (1963) The estimation of phosphorus fertiliser requirements of wheat in southern New South Wales by soil analyses. Australian Journal of Experimental Agriculture and Animal Husbandry 3, 190-197. doi:10.1071/EA9630190

Cowley T, Oxley T, MacDonald N, Cameron AG, Conradie P, Collier C, Norwood D (2015) 'The 2010 pastoral industry survey: Northern Territory wide.' (Northern Territory Government: Darwin, NT, Australia)

Davidson BR, Martin BR (1965) The relationship between yields on farms and in experiments. The Australian Journal of Agricultural Economics $\mathbf{9}$, 129-140. doi:10.1111/j.1467-8489.1965.tb00335.x

de Brouwer CHM, Cilliers JW, Vermaak LM, van der Merwe HJ, Groenewald PCN (2000) Phosphorus supplementation to natural pasture grazing for beef cows in the Western Highveld region of South Africa. South African Journal of Animal Science 30, 43-52. doi:10.4314/sajas.v30i1.3875

Dillon J, Anderson J (1990) 'The analysis of response in crop and livestock production.' 3rd edn. (Maxwell Macmillan Publishing Corporation: Oxford, UK)

Dixon RM (1998) Improving cost-effectiveness of supplementation systems for breeder herds in northern Australia. Project DAQ.098 final report. Meat and Livestock Australia, Sydney, NSW, Australia.

Dixon RM, Doyle PT (1996) Straw and low quality roughages as drought feeds. In 'A users guide to drought feeding alternatives'. (Eds J Rowe, N Cossins) pp. 61-74. (University of New England: Armidale, NSW, Australia)

Dixon RM, White A, Fry P, Petherick JC (2003) Effects of supplement type and previous experience on variability in intake of supplements by heifers. Australian Journal of Agricultural Research 54, 529-540. doi:10.1071/AR02091

Dixon RM, Coates DB, Holmes WE, English B, Rolfe J (2011) Phosphorus nutrition and management: overcoming constraints to wider adoption. In 'Proceedings of the Northern Beef research update conference', 3-4 August 2011, Darwin, NT, Australia. pp. 102-109.

Dixon RM, Coates DB, Mayer RJ, Miller CP (2016) Productivity and phosphorus content of rib and tail bones in reproducing cows ingesting diets deficient or adequate in phosphorus. Proceedings of the Australian Society of Animal Production 31, 93-94.

Dixon RM, Kidd LJ, Coates DB, Anderson ST, Benvenutti MA, Fletcher MT, McNeill DM (2017) Utilising mobilisation of body reserves to improve the management of phosphorus nutrition of breeder cows. Animal Production Science 57, 2280-2290. doi:10.1071/AN17324

Dixon RM, Fletcher MT, Goodwin KL, Reid DJ, McNeill DM, Yong KWL, Petherick JC (2019) Learned behaviours lead to bone ingestion by phosphorus-deficient cattle. Animal Production Science 59, 921-932.

Foran BD, Stafford Smith DM, Niethe G, Stockwell T, Michell V (1990) A comparison of development options on a northern Australian beef property. Agricultural Systems 34, 77-102. doi:10.1016/0308-521X (90)90095-8

Henderson A, Perkins N, Banney S (2012) Determining property level rates of breeder cow mortality in northern Australia. Project B.
NBP.0664 final report. Meat and Livestock Australia, Sydney, NSW, Australia.

Holmes WE (1990) Phosphorus and beef production in northern Australia. 11. A case study approach to the economic assessment of phosphorus supplementation. Tropical Grasslands 24, 250-255.

Holmes WE, Chudleigh F, Simpson G (2017) 'Breedcow and Dynama herd budgeting software package. A manual of budgeting procedures for extensive beef herds.' (State of Queensland, Department of Agriculture and Fisheries: Brisbane, Qld, Australia). Available at https://www.daf.qld.gov.au/animal-industries/beef/breedcow-anddynama-software [Verified May 2017]

Jackson D, Rolfe J, English B, Holmes B, Matthews R, Dixon R, Smith P, MacDonald N (2012) 'Phosphorus management of beef cattle in northern Australia.' (Ed. I Partridge) (Meat and Livestock Australia Ltd: Sydney, NSW, Australia)

Kerridge PC, Gilbert MA, Coates DB (1990) Phosphorus and beef production in northern Australia 8. The status and management of soil phosphorus in relation to beef production. Tropical Grasslands 24, 221-230.

Makeham JP, Malcolm LR (1993) 'The farming game now.' (Cambridge University Press: Cambridge, UK)

Malcolm B (2000) Farm management economic analysis: a few disciplines, a few perspectives, a few figurings, a few futures. In 'Proceedings of the annual conference of Australian Agricultural and Resource Economics Society'. (Australian Agricultural and Resource Economics Society: Sydney, NSW, Australia) Available at https:// ageconsearch.umn.edu/bitstream/171920/2/malcolm.pdf [Verified May 2018]

McCosker T, Winks L (1994) 'Phosphorus nutrition of beef cattle in northern Australia.' (Department of Primary Industries: Brisbane, Qld, Australia)

McGowan M, McCosker K, Fordyce G, Smith D, O'Rourke P, Perkins N, Barnes T, Marquart L, Morton J, Newsome T, Menzies D, Burns B, Jephcott S (2014) Northern Australian beef fertility project: CashCow. Project B.NBP.0382 final report. Meat and Livestock Australia, Sydney, NSW, Australia.

MLA (Meat and Livestock Australia) (2018) Market information statistics database. Available at http://statistics.mla.com.au/Report/List [Verified August 2018]

Neithe GE (2011) New R and D for better herd health and productivity. In 'Proceedings of the Northern Beef research update conference', 3-4 August 2011, Darwin, NT, Australia. (pp. 34-40).

Robinson LJ, Barry PJ (1996) 'Present value models and investment analysis.' (The Academic Page: Northport, AL, USA)

Schatz T, McCosker K (2018) Phosphorus supplementation of Brahman heifers in phosphorus deficient country in the NT. In 'Animal production 2018. Fostering innovation through the value chain. Proceedings of the 32nd biennial conference of the Australian Society of Animal Production', 2-4 July 2018, Wagga Wagga, NSW, Australia. (Eds M Friend, S Hatcher, D Hopkins, P Hynd) p. 1x.

Spangenberg HP (1997) Phosphorus supplementation to grazing beef cattle at two sites in the Northern Cape. PhD Thesis, University of the Orange Free State, Bloemfontein, South Africa.

Ternouth JH, Coates DB (1997) Phosphorus homeostasis in grazing breeder cattle. Journal of Agricultural Science, Cambridge 128, 331-337. doi:10.1017/S0021859696004145

Tudor GD, O'Rourke PK (1980) The effect of pre- and post-natal nutrition on the growth of beef cattle. 2 . The effect of severe restriction in early post-natal life on growth and feed efficiency during recovery. Australian Journal of Agricultural Research 31, 179-189. doi:10.1071/AR9800179 
Wadsworth JC, McLean RW, Coates DB, Winter WH (1990) Phosphorus and beef production in northern Australia. 5. Animal phosphorus status and diagnosis. Tropical Grasslands 24, 185-196.

Whish G (2011) 'Land types of Queensland. Version 2.0.' Prepared by the Grazing Land Management Workshop Team, PRO7-3212. (Department of Employment, Economic Development and Innovation: Brisbane, Qld, Australia) Available at http://www.futurebeef. com.au/knowledge-centre/land-types-of-queensland/ [Verified June 2019]
Winks L (1990) Phosphorus and beef production in northern Australia. 2. Responses to phosphorus by ruminants: a review. Tropical Grasslands 24, 140-158.

Winter WH, Coates DB, Hendricksen RE, Kerridge PC, McLean RW, Miller CP (1990) Phosphorus and beef production in northern Australia. 4. The response of cattle to fertiliser and supplementary phosphorus. Tropical Grasslands 24, 170-184.

Handling editor: Wayne Bryden 